\title{
THE SIGNIFICANCE AND PURPOSE OF ANCIENT MANUSCRIPT \\ FOR THE NATION'S CULTURE AND CHARACTER DEVELOPMENT THROUGH THE HISTORY TEACHING
}

\author{
Ufi Saraswati ${ }^{1}$
}

\begin{abstract}
The Indonesian nation conserves many ancient manuscripts. The ancient manuscripts are spread out throughout Indonesia's archipelago, even though the total numbers of the ancient manuscripts in each area are not the same. The ancient manuscripts may be treated as documents of a nation, due to the fact that the documents may be referred to as writings containing pertinent information.. Nowadays the teaching of history by utilizing ancient manuscripts are rarely conducted by teachers. However, it is necessary to have the efforts in comprehending the ancient manuscripts that any information of the past be passed to the current and future generations. The teaching of history based on scarce resources presents certain challenges to the teacher. In this country, history has been one of the core subjects in the curriculum, since elementary school, which leads to the question whether the teaching of history has been well operated? In fact, the teaching of history in many schools is merely the transferring the teacher's knowledge to the students in class through one-way communications. The students have become passive objects that have the duties to memorize notes given by the teacher in order to respond to the questions that will be examined. This type of history teaching method has caused the history subject uninteresting. A successful method of teaching history shall be by constructing a historical memory' along with an 'emotional memory'. The study of ancient manuscript on history teaching is one of the many methods that can instigate "emotional memory". After students are provided with facts of history to construct "historical memory" in class, the emotional memory can be delved due to the study of ancient history. Various alternative methods in relation to the modification of history teaching are necessary to be developed. One of the methods that can be implemented is the capitalization of ancient manuscript for the History teaching, particularly for the development of the Nation's Culture and Character.
\end{abstract}

1 Ufi Saraswati is lecturer of History FIS UNNES. This Article has been reviewed by Prof. Dr. Said Hamid Hasan (Indonesia University of Education), Prof. Dr. Dadang Supardan, M.A (Indonesia University of Education, and Prof. Dr. Hansiswany Kamarga, M.Pd (Indonesia University of Education). 
Key Word: archipelago, history teaching, character development, ancient manuscript, historical memory

\section{Introduction}

The history of a nation can be unraveled from the study or the research of authentic data sources. The source of data for the history teaching derives from written sources and unwritten sources. The unwritten source incorporates buildings or debris of a location that often consists of a wide area. In Indonesia for instance, the unwritten source can be found in the Majapahit Kingdom area in East J ava. The written sources shall include Epigraph, Charter, Documents, and Inscriptions written on gravestones, and Manuscripts, particularly ancient manuscripts.

The unwritten source or the written source that serves as data sources for the teaching of history often provides quite pertinent information. One of the conveyed pertinent information is about the Social Culture of the community within a certain period. In comparison between the written and unwritten sources, and therefore the written sources is more suitable for the teaching of history and culture It is through the written document that we can learn more conspicuously and accurately the way of thinking of the nation that had prepared the document.

The content of a manuscript or written document often provides information on the nation's cultural aspect of the respective community. The information that can be conveyed from ancient manuscript includes philosophy, religious life, beliefs, technical manners such as residential development, procurement of field, the teaching of various types of expertise and skills and other matters related to the overall necessity of the respective nation.

Nowadays the government has not given its attention to the conservation of ancient manuscript from being damaged. There are hundreds of precious ancient manuscripts from the viewpoint of history that are predicted to be in the public hands in damaged conditions. It cannot be disputed that the ancient manuscript are made of materials that are easily decayed. In England, our manuscripts are carefully inventoried in a catalogue prepared by M.C. Ricklefs dan P. Voorhoeve. According to the catalogue, our manuscripts have existed in England since the beginning of the $17^{\text {th }}$ century, even prior to that.

The manuscripts are identified as written in various dialects such as Aceh, Bali, Batak, Bugis, J ava (ancient), Kalimantan, Lampung, Madura, Makasar, Melayu, Minangkabau, Nias, Rejang, Sangir, Sasak, Sunda (ancient), dan Sulawesi (apart from Bugis and Makasar). The total of all of the existing manuscripts is more than 1,200. All of them are well stored in around 20_libraries and museums in numerous cities in England. Most of the collections are kept in the British Library and School of Oriental and African Studies. At both places, archeologists, historian, and philologist from all over the world, including Indonesia, often conduct literary research. 
According to Annabel Teh Gallop, British Library staff, upon her visit to J akartain the 1990s, various tales, quatrain, primbon (a handbook which contains predictions, calculations of unlucky days, etc.), and letters, up to the commerce transactions from the $15^{\text {th }}$ century were stored at her workplace. Those sources are often used by Foreign and Indonesian teachers. According to Annabel, due to the fact that they are well kept and maintained, they have a much larger role compared to the National Library of the Republic of Indonesia that also collecting ancient manuscripts.

There are numerous Indonesia's ancient manuscripts kept in the Netherlands. As a colonizer nation, the Netherlands had put a large attention on ancient manuscripts written by the people of the Indonesian Archipelago. The Netherland's government of the time had capitalized on ancient manuscripts in order to learn the customs and traditions, culture or habits of the Indonesians, as well as historical voyage of the Indonesian prior to their visit in the $16^{\text {th }}$ century. The manuscripts are stored in a number of libraries and museums, which are in Amsterdam, Leiden, Delft, dan Rotterdam. Different from the English, the Indonesian manuscripts in the Netherlands are categorized as "masterpiece", which is comprehensible as the Netherlands had occupied our country longer than the British.

Amongst the existing manuscripts, one of the well known manuscripts is the manuscript of Nagarakretagama. The manuscript was returned to Indonesia in the 1970s by Queen Yuliana to President Soeharto; however, the content of the manuscript had been completely stripped by the Dutch scholars, and thereforewe only receive the "wastes" that are nearly useless. It has been predicted that up to this day therearemany manuscripts of Indonesia residingin around 30 countries. They have mastered the knowledge of preserving ancient manuscripts. In order to prevent the ancient manuscripts to become more damaged, they have copied the ancient manuscripts into microfilms. The ancient manuscripts are preserved in that method certainly gives positive impact to their users, as microfilms are not only practical, yet ancient manuscripts are prevented from being damaged.

Ironically, in our own country such preservation has never been conducted due to lack of human resources, technology, and funds. It has been due to foreign aids that a number of ancient manuscripts are copied into microfilms. J avanese manuscripts owned by the Royal Palace of Yogyakarta, for example, have been managed by Dr. J ennifer Lindsay from Australia. Meanwhile, the lontar (the leaf of Palmyra palm, used for writing before the introduction of paper) manuscripts of Bali were computerized with the sponsor of the giant corporation, IBM. In 1989, the British government presented as gifts to Sri Sultan Hamengku Buwono $\mathrm{X}$ hundreds of J avanese manuscripts previously kept in England. This is due to the fact that some of the J avanese manuscripts derived from the Yogyakarta area. In 1991, the National Library received from the British government a gift in the form of recorded manuscript microfilm written in various local languages, as a token of their concern on the Indonesian heritage. It shall certainly be shameful if our nation's pace on the ancient manuscripts are below their level of appreciation. 


\section{The Significance and Purpose of Manuscript}

The ancient manuscript in English is referred to as manuscript and in Dutch, as handscript. Manuscript is an authentic handwriting aged at the least of 50 years and contain pertinent significance to the civilization, history, culture, and knowledge. In Indonesia, there are three types of manuscripts, which are: 1 . The Manuscript of Islam, which is the manuscript written in the Arabic language and Arabic writing; 2. The Manuscript of J awi, which is the manuscript written in Arabic script, yet in Malay language with a few additional vonim to maintain the Malay accent; 3. The Manuscript of Pegon, which is the manuscript written in Arabic script yet using local language such as Javanese, Sundanese, Buginese, Buton, Banjarese, Acehnese, etc.

As inheritance of the past, the ancient manuscript can provide information on various aspects of the community's livelihood in the past such as politics, economy, social cultural, traditional medicine, quake screen or natural indications, human physiology, etc. Early information respective to this information can be found in the contents of manuscript for everyone to learn. The manuscripts are theidentity, pride, and precious cultural heritage. In terms of social culture, the manuscripts contain relevant values to today's livelihood. Thus, it is our responsibility to reveal the 'wisdom' it holds. Apart from cultural documentation, manuscripts can also be an education object to teach the contained values and contents. The values are highly required for the relevance of good values of the past for today's implementation.

Another definition of thereferred manuscriptin thisjournal is the writingsthat are directly written with stationeries and by hand, not by mechanical stationeries, such as typewriter, printing machine, computer. The manuscript writing was conducted in the past, prior to the invention and widely usage of mechanical stationeries. In Sundanese region, including Banten, manuscripts were produced since the era of Sunda Kingdom (end of the $7^{\text {th }}$ century up to the $16^{\text {th }}$ century) and only concluded towards the end of the $20^{\text {th }}$ century.

The birth of manuscript is closely related with the rising of reading-writing skills amongst the community. This reading-writing skills is closely related to the emergence of language as a symbol of voice sounded by humans. The human voice subsequently is referred to as verbal language is a social communication tool amongst them. In Sunda region the evidence of the language existence was known for the first time through the estate of epigraph, which is inscription on rocks. The referred epigraph is estimated to derive from around the mid of the $5^{\text {th }}$ century, during the existence of Tarumanegara Kingdom (at the end of the $4^{\text {th }}$ century up to the $7^{\text {th }}$ century). There are seven epigraphs carved written in the language of Pallawa and Sanskerta

The existence of ancient Manuscript as a cultural heritage clearly provides recorded evidence on our culture in the past. The manuscripts have become a portrait of an era that describes various matters of the past, and therefore they have very important and strategic values. Hence, solid actions are required in preserving the manuscripts. The manuscript has become a documentation of 
culture that does not only contain traditional values, but ancient manuscript is also a media that observes and study other cultures (including our own culture).

In a few manuscripts of Riau Malay laws, such as Kedah Laws, Melaka Laws, J ohor Laws and Melaka Sea Laws, there are many texts describing the overall traditional livelihood of Malay. The collection of manuscripts illustrates the livelihood of Malay community in the past that afterwards were given an evaluation and interpretation. As stated by J elani Harum in "The Study of the Manuscript of Malay's Customary Lawsin London". Foreign teachers from London have implemented the Laws for the need of the London community. They have developed the manuscript of Malay Laws as a media to comprehend the customs and culture of Malays. As teachers of ancient manuscript, they communicate with the authentic local community (Malay) based on the obtained data from the manuscript, and from the teachings, they have produced a few policies that are well considered and implemented in their Laws in London.

Meanwhile for certain countries, such as Malaysia, they have purchased personal collection manuscripts of Minangkabau community for private usage, in order to capitalize particular necessities, such as translation of our culture's identity to be practiced into their culture. Therefore, the government of Riau is attempting to capitalize the ancient manuscript for the purpose of studying the culture in the past that will be further handed down to the generations today. Apart from that, Malay's scholars of Islam and intellectuals have created a few manuscripts as pillars or manuals of their knowledge. To Riau, nowadays the content of the manuscript has influenced them, such as in religion, languages, literature, law, history, customs, and education aspects. Based on those matters, the Riau government is utilizing the manuscripts to develop and reunite the language and culture of Malay in Southeast Asia, particularly in Riau and the surrounding areas.

\section{Types of Ancient Manuscripts or Manuscripts in Indonesia}

The ancient manuscripts in Indonesia are not well known by Indonesia's own community, and therefore only a few are concern about the cultural heritage of the past, whereas the ancient manuscript contains benefits and wisdom for today's generation. Contents of some ancient manuscripts from various regions that are collected by the National Library are described below:

1. The Manuscript of Pariaman City's History (Latin script, Malay language, paper material). This manuscript is written in the Pariaman city by Baginda Said Zakaria. The manuscript consists of ten chapters, containing justice of Pariaman city, the community's livelihood, birth ceremony, wedding ceremony, death ceremony, and residence building ceremony. Apart from that there are also descriptions on the situation and buildings of the Batu Pasar Pariaman mosque, the biography of Syekh Muhammad Jamil al-Khalidi (a moslem personage in Pariaman) and the situation during Ramadhan, including 1 Syawal (the tenth month of the Islamic calendar) in Pariaman city. 
2. The Manuscript of the origins of Sambas Kings (Arab and Latin scripts, Malay language, paper material). The manuscript is in the form of prose. Firstly it contains the history of King Sapudak who had governed in the old city from generations to generations. It was told that King Fangah of Brunei migrated to Sambas. He had five sons and each of them had become king.

3. The Chronicles of Maluku (Arab scripts, Malay language, paper material) The manuscript is in the form of prose. The contents begin with stories of the miracles of kings from Turkey, China, Netherlands and other countries, and then it contains the chronicle of the archipelago of Maluku.

4. The Chronicles of Lombok (Java script, Javanese language, paper material)

The manuscript is in the form of verses. It contains the history of Lombok starting from the story of the prophecies, up to the defeat of Lombok by the Karangasem kingdom.

5. The Tales of Aceh (Arab script, Arab and Aceh language, paper material)

This manuscript is in the form of prose. It contains quatrains to Muhammad the Prophet. Apart from that, it also contains prayers.

6. The Manuscript of Bomakawya (Balise script, Bali language, lontar material) This manuscript is in the form of prose and with illustrations. It contains an extraordinary story on the war between Kresna and Boma.

7. The Sureq of Baweng or Letter of Nuri (Bugis script, Bugis language, lontar material)

Themanuscript is in the form of prose. It contains the journey of Sawerigading upon his search for a prospective good wife, completed with the story of the nuri bird that contains advice on how to propose to a woman, and some teachings of character.

8. The Manuscript of Carita Parahyangan (Ancient Sunda script, Ancient Sunda language, lontar material)

The manuscript is in the form of prose, consists of 45 pages and every page consists of four rows of writings. The story begins from the tales of Sang Resi Guru from generations to generations up to the kings in West J ava.

9. The Manuscript of the History of Banten (Arabic script, Java language, paper material)

This script is in the form of verses. It contains the genealogy of Muhammad the Prophet and his descendant. It also narrates the biography of Sunan GunungJ ati who descended the sultans of Banten.

10. The Book of Laklak (Batak script, Batak language, wooden skin material) This manuscript is in the form of prose. It consists of 38 pages. It contains the story of Tuan Saribu Raja who has many children and grandchildren. It is also detailed on how to make a fortification of self force, good and poor fortune, and necessary offerings for daily production.

11. The Manuscript of Japar Sidik (Arab script, Sunda language, paper material) This manuscript is in the form of prose. It contains words of wisdom based on the Islamic teaching and the world of Sundanese ideas, such as the advantages of deliberation, the good days to hunt and travel, trade, descendant and laudable characteristics. 
Apart from that there are also some manuscripts of influencing ancient manuscripts in the Indonesian archipelago, which is the eldest Islamic Manuscripts in the Indonesian archipelago found in Terengganu, Malaysia. This manuscript is called Batu Bersurat written in 1303 (14 $4^{\text {th }}$ century). This writing states the spreading of Islam and the Muslims at the time. This manuscript has been researched by Historians and Islamic Archeologists in Malaysia such as Prof Naquib Alatas and others. All of them concluded that the manuscript is the eldest in the Southeast Asia.

In 1310 ( $14^{\text {th }}$ century) was also found quatrains on Islam written in Malay language in the Jawi letters in Minya'Tujoh, Aceh. Therefore, the experts had agreed that the development of Islamic scholar's works written in J awi letters had been developed in the $14^{\text {th }}$ century during the period of the Pasai Ocean Empire and other Islamic Empires in the Peninsula of Malaka.

During younger years of the $16^{\text {th }}-17^{\text {th }}$ century in Aceh there were plenty of manuscript writers, for example, Hamzah Fansuri, who is also known as a renowned Sufi leading figure during his time. Furthermore, there was Syekh Nuruddin ar-Raniri alias Syeikh Nuruddin Muhammad ibnu 'Ali ibnu Hasanji ibnu Muhammad Hamid ar-Raniri al-Quraisyi. He was known as an Islamic scholar who has a duty as Qadhi al-Malik al-Adil and Mufti Muaddam in Aceh Royal Palace during the leadership of Sultan Iskandar Tsani in the 16th century. One of his infamous works entitled"Bustanul Salatin”. Syeikh Abdul Rauf alSingkili was also nominated as Mufti dan Qadhi Malik al-Adil in the Aceh's Royal Palace for the period of four queens, and wrote many Islamic manuscripts.

Their works did not only develop in Aceh, but also in Sumatera, the Peninsula of Malaka up to South Thailand. Their works have also influenced the way of thinking and the early civilization of Islam in the islands of Java, Sulawesi, Kalimantan, Nusa Tenggara, Maluku Archipelago, Buton, up to Papua, and therefore heritage of the Islamic scholars' works are found in the regions. The next development shows the works of Islam in other regions such as, the Book of Sabilal Muhtadin written by Syekh al Banjari in Banjarmasin. There are also some in Palembang. In Banten, there was Syekh al Bantani who had written many manuscripts. All of these manuscripts had become the reference of followers and leaders of the time. Manuscripts were also discovered in other regions such as the Tales of the Pasai Kings, the Tales of Melayu, the Tales of Aceh, the Tales of Hasanuddin, Chronicles of the J awi Land, Chronicles of Cirebon, Chronicles of Banten, The Story of Purwaka Caruban Nagari. In Nusa Tenggara Bima Kingdom Notes, Bo'Sangaji Kai Bima Kingdom Notes were discovered. In Sulawesi there are Goa Tales, Wajo Tales and others.

Moreover, there are manuscripts of Pegon letters. Generally found in Central Java, East J ava and Tatar Pasundan. The eldest work of Pegon letters is for instance, by Sunan Bonang or Syekh al Barri entitled "Wukuf Sunan Bonang”. This manuscript was written in the $16^{\text {th }}$ century in the middle age J avanese language blended with the Arab language. This manuscript is a translation and also interpretation of the Ihya Ulumuddin by Imam al-Ghazzali. This manuscript was discovered in Tuban, East J ava. In this works, Sunan Bonang wrote, "This 
manuscript was utilized by the Waliallah and the Islamic scholars, and then I translated it and for my fellow peers (friends) sharing in the same struggle for the purpose of spreading Islam in the Java land." This works is an example that in the $16^{\text {th }}$ century was the development period of Islamic kingdoms in the Indonesian archipelago, and at the same time, was the development of the works of the Islamic scholars that played a major role in the expansion of Islam in the Indonesian archipelago.

\section{The Existence of Ancient Manuscript or Current Manuscript}

Most of the ancient manuscripts as aforementioned above are in the Netherlands, to be exact at Leiden University. During the VOC and colonization, the Dutch had collected and stolen and looted classic Islamic manuscripts for their personal use. Some of them were for the purpose of the facilitation of colonization and erasing the traces of Islamic civilization from their original source in the Middle East. The Muslims in the Indonesian archipelago had lost their authentic source of Islamic development through the seizing of works of the Islamic scholars. This was the reason behind the hundred years colonization.

Apart from the ones in the Netherlands, the ancient Manuscript also exists in the National Library. The manuscript in J awi letters and Malay language in the National Library in J akarta are only around 1,000 manuscripts, whilst the other manuscripts in Arab letters or Arab language are less. Meanwhile in the Netherlands, the Islamic manuscripts from Indonesia that are written in J awi language has reached more than 5,000 manuscripts. The total is larger for the manuscripts written in Pegon letters or Arab letters and Arab language.

Physically restoring manuscript is more difficult than it looks because the physical form truly shows its age of centuries; hence many parts are extremely fragile, even that nowadays, according to the International Convention, objects of cultural pledge including manuscript from a nation must be returned to the respective nation. For instance, a manuscript that was physically returned to Indonesia is the Book of Negara Kertagama. This Book was obtained by the Dutch during the Lombok war. Another example is the Pradnya Paramitha Statue from Singasari era has been returned. The horse saddle of Prince Diponegoro is returned to the native land by the Dutch, including a trunk of rings, gold and diamonds from Lombok. If the returned manuscript is physically fragile, the government can document it by transferring it into digital microfilm.

The National Library has documented some of the manuscripts by recording several of them into microfilms. During the tsunami of Aceh, original Aceh manuscripts have been missing, and therefore documentation by digital microfilm of the remaining manuscripts are now conducted. Luckily, in a Pesantren (Islamic boarding school) in Tanobe, Nangro Aceh Darussalam, there are more than 2,000 classic manuscripts from the $13^{\text {th }}$ century to the $19^{\text {th }}$ century works of Islamic scholars in Aceh and the Middle East. The salvation process should have been done by the Provincial Government. If it shall be beyond the capability of 
the government, then it should cooperate with university institutes. In West J ava, the cataloging of classic manuscripts from the stone age up to the $19^{\text {th }}$ century in Sundanese language or other languages from various countries. Manuscripts are collected, catalogued, recorded into microfilm and now can be studied. Malaysia has also done it, so has South Sulawesi. There must be a movement of ancient manuscript salvation, including the Islamic manuscript nationally.

\section{The Utilization of Ancient Manuscript for the Teaching and Writing of History}

The teaching of Indonesian history utilizing sources (written) is rarely practiced, and it seems that it has not been developed, particularly by the Indonesian teachers. Perhaps this is due to the rare characteristics of the teaching source itself. The scarcity is not only scarce or difficult to obtain, but also unique, and even exclusive. Thus, the rare source is a source of unique and difficult to find collection. In other words, the rare source is inherently scarce. It is also clear that the scope of the scarce source's distribution is limited, as it is generally not multiplied through printing machines or other transmission media.

The scarce source does not always concerns a time period that is "old", and therefore a time gap is extended with the living period of the teacher. Soon it can be identified that scarce source are ancient manuscripts or manuscripts that are handwritten. There are many manuscripts that are associated with the"classic period" of kingdoms in the past. In the treasure of history, the categorization of scarce source is expandable by incorporating chronicles, daily notes, family documents, memoirs, ancient manuscripts/ formal documents and also unwritten sources such as customs, folklore, and even mishmash witchcrafts dan myths.

We cannot agree more that the teaching of history relying on scarce sources has its own challenges for the teachers. This journal discusses the scarce sources and/ or the scarcity of sources as an aspect of historiography problem, particularly in the teaching of history. The main question is what implications are the scarce sources for the teaching of history. Some of the works of teaching mentioned in this journal shall serve as supporting illustrations in order to obtain a clearer picture of the situation.

At the beginning of its development, research and the history teaching was not scientific. The working method of history writers had been limited on the efforts to discover history sources in the forms of ancient books or formal letters and various reports. The documents have been read by the teachers for the purpose of quoting parts that are relevant to the history theme that will be written. There were no efforts to investigate the history source; they themes were usually limited to important people's biography, glory, and the falling away of a kingdom, wars, and diplomacy between kingdoms. In short, the general themes of history teaching on those eras were inclined towards politics and military aspects. 
Modification on the methods of history writing had begun in the $17^{\text {th }}$ century. The cultural situation was characterized by the development of science and critical intellectual attitude that appeared amongst history writers. A French scholar, J ean Mabillon (1632-1707) was viewed as the founding father of history called diplomatic, in accordance with the written book, Dere Diplomatica (1681). Historians started to discover various methods to critically study documents or history sources in order to obtain the teaching of history that is close to being accurate. Apart from that, historian Leopold von Ranke (1795-1815), introduced the principals of critical selection on the history data to specify the facts based on wie es eigentlich gewesen, history as it happens (Barnes, 1963).

Nowin general, the development of scientificmethods in history is developing. It is not spared from the acceptance of history as equivalent to other knowledge and has become a part of the curriculum in universities of many countries at least since the $19^{\text {th }}$ century. Basically, the method of history teaching consists of three important aspects. The first aspect is the method of discovering the history source that is commonly referred to as heuristic. The history teachers today are "advantaged" by the assembling of government and non-government organizations/ agencies functioning as storage of history source, such as national/ regional library, national/regional ancient manuscript office, central of teaching, et cetera. The system to discover the history source has also been designed, supported by professionally experienced or educated staffs in conjunction to the sophisticated information technology systems. Even so, the process of discovering the history source, if any are considered rare, remains a challenging work as there are many obstacles.

The second aspect, after the source is discovered, is to examine the content of the source. How far can the content be acceptable as a trusted source? In order to dig up information contained in the source, particular expertise are required, such as diplomatic, as previously mentioned; paleography or methods of understanding ancient writings; chronology to verify the effective dating system in the past and present; lexicography or methods of specifying the meaning of terminologies used in the past that are no longer effective today; numismatic related to the ways of specifying the value of ancient currency; metrology or the method of specifying the effective measurement and scale of different eras; toponimi or the method of specifying the names of places in the past; et cetera (Barnes, 1963).

The third aspect is related to the writing of the teaching outcomes of the sources. Writing not only requires writing skills and the governance of language principals, but also includes the comprehension of terminology as well as particular theories relevant to the researched history theme. In general, history experts argue that proficiency of teaching and proficiency of writing the teaching results are two aspects that are inseparable.

From the short description above, it can be concluded that the first and second aspects of history methods are interrelated with the source. Conventionally, the referred source is the primary source, particularly in writing. The basic viewpoint is that the primary source is part of the evidence of the past that has become part of the examination source material, which becomes the pillar of an event, 
occurrence or even a history that can be reconstructed. As time goes by, the primary source becomes farther from the living era of the teacher in a later day, thus one day it will contain the rare characteristic of the source. Meanwhile the third source of the method is closely related with the development of the theory and methodology that cannot be discussed in this journal particularly.

It has been mentioned that the teaching of history that is dependent on rare sources will provide certain challenges to the teachers. The problem lays on the reality that the physical appearance of the ancient sources is generally worn out and fragile. Efforts to record them into different format (celluloid, disc) can aid in handling the susceptibility, but may also develop a new problem such as dependability of reading media, computer illiterate, et cetera. Afterwards, the "true" challenge will emerge in relation to the content or substance, scripts and languages that may not be empowered by the teacher. The obstacle becomes more complex if the collection of the scarce source is stored in a "hidden" area or far from the domicile of the teacher.

It is without any doubt that within the scarce source, various information of the past is overflowing. This means that the scarce source is not identical with the scarcity of the information content that is required in the teaching of history. A teacher of the beginning of the J ava history, H.J. de Graaf for example, had proven that "only" through learning the traditional history such as chronicles (in addition to other sources), he has successfully presented the J avanese history aspects in detail. As a Dutchman, he learnt from a Javanese philology R.M. Ngabehi Poerbatjarakato "conquer" various difficulties on dealing with traditional sources, particularly from the language aspect. The outcomes are the complete history of Mataram, from its appearance, development, up to the falling away of the kingdom (refers to De regering van Panembahan Senapati Ingalaga (1954), De regering van Sultan Agung (1958) De regering van Sunan Mangku - Rat I Tegal-Wangi, 2 volumes (1961, 1962), and other works.

The study of H.J . de Graaf can be categorized as a typical conventional history that determines important events at the elite level. Meanwhile, broader social aspects do not receive proper attention. Even so, the hard work of de Graaf for tens of years has been regarded as a strong foundation for scientific study on the history of J ava during the $16^{\text {th }}-18^{\text {th }}$ centuries. According to historian M.C. Ricklefs who was once a student of de Graaf, the important meaning of his teacher's works lies on the fame he gained from preparing a foundation from a history also preparing reference of sources for those who follow his footsteps.

On a later day, Ricklefs showed his ability to continue the efforts of de Graff in preparing a reconstruction of the history of J ava based on rare sources. Three of his main works (refers to J ogjakarta under Sultan Mangkubumi 1749-92 (1974), War, Culture and Economy in J ava 1677-1726 (1993), dan The Seen and Unseen Worlds in Java 1726-1749 (1998) were a comprehensive trilogy that views the development of the history in J ava, particularly within the circle of the royal palace, during the $17^{\text {th }}-18^{\text {th }}$ centuries. In his studies, Ricklefts has demonstrated his area of expertise in processing and analyzing local sources intensively apart from other types of sources. Different to de Graaf who stresses his studies on 
the elite level, concentrating on political and military aspects, and therefore the attention of Ricklefs expands on other aspects. To summarize, Rickef illustrates the dynamics of the Javanese society surrounding the royal palace and their interaction with foreign force (Western) that appeared later on. Theinterrelations consists of war or military and political, economy, culture, literature, as well as religion. The religious aspect (Islam) was shown as the efforts of the J avanese to discover their identity amongst the pressure of foreign power that is VOC.

The footsteps of Ricklefs was followed by another foreign graduate who also utilized rare sources intensively in his studies, such as Peter Carey, Ann Kumar, Vincent Houben, and many more. The attention on the old history outside of J ava was also shown by Denys Lombard The Aceh Kingdom During the Era of Sultan Iskandar Muda 1607-1636 (1986), dan Leonard Andaya (The Heritage of Arung Palaka (1981). Some examples of the study were randomly selected and can still be extended by incorporating works of non-history scholar such as philology and literature, for instance Henri Chambert-Loir who prepared the Bima Kingdom (2004). The information on scarce sources was enriched by catalogue compiling service of ancient manuscripts and document collector of ancient manuscripts.

From the Indonesian scholars, as previously mentioned, there are still very few who work on scarce sources as the material of historical studies. Amongst the very few is Aminuddin Kasdi who wrote a dissertation entitled Perlawanan Penguasa Madura atas Hegemoni J awa (or The Resistance of the Arbiter of Madura on the Hegemony of J ava, published in 2003). A number of unpublished and published manuscripts are important sources in this study. Although the Kasdi's study on the final era of Mataram (18 ${ }^{\text {th }}$ century) was particularly on the relationship between the central and regional, it has become important because they have the echo of the problems faced today, which is the regional autonomy. It shows that there is relevance between the old days and today.

\section{Innovation in the History Learning and Teaching}

Learning has becomea dominant part in achieving the quality of the education process and the graduates. Learning is heavily dependent on the capability of the teacher in packaging and executing the process of education. A well and accurate execution of teaching will have a very dominant contribution to the students. On the contrary, a poor execution of teaching will result in having difficulties in developing the students' potentials. Therefore, a teacher must comprehend the reason for the innovation of education, particularly in the teaching of history.

The word "innovation" signifies update or invention. Nonetheless, the word innovation is also utilized to translate the word Invention and Discovery. These three words actually have different meanings. Discovery is an invention of something that is in a form of an object or matter that has already existed yet has not been exposed to other people. Invention is the finding of something brand new as the outcome of a human's creations. The object or item found has never existed before. Meanwhile innovation refers to an idea, object, event, methods felt 
by or observed by someone or a group of people and that something is brand new, either as an outcome of Invention or Discovery. In this point of view, we learn that the teaching of innovation is a new concept and conducted on purpose to increase the capability in order to achieve the goal of teaching. The innovation of teaching is conducted to assist teachers and students in arranging and organizing the learning process in order to achieve the purpose of study.

Learning is an activity that differentiates human beings from other creations. Humans conduct learning activities throughout their lives. A series of learning process is conducted by following formal, informal, or non formal education. The learning process is conducted to obtain change within the executor, be it knowledge, attitude, or skills. The change is a result of the process of natural or designed experience. Learning is not only performed by students, but an activity that is carried out by every human for the purpose of solving any problems faced and to adjust to the environment. The characteristic of learning is the change of attitude as an outcome of the interaction of an invidual with the environment. The attitude itself is permanent.

The process of teaching cannot be separated from the process and outcomes of learning. Teaching refers to any and all designed activities to support the process of learning that is marked by a change in attitude of an individual in accordance with the objective of teaching. This process of teaching must be well organized in order to develop a good process of learning and to achieve the best outcome of learning. Therefore, the types of learning process and outcomes become the centre of attention of the teaching method.

Until now history is still categorized as number two, even a certain number amongst a few subjects taught in schools. Thus whatever education background a teacher has, and with the consideration that history is a memorizing and easy subject, and therefore any teacher can teach it. It is certainly ironic when the government has started to proclaim professionalism in teaching by launching a certificate of teaching. However, in many schools are found teachers who are giving out history subjects without the proper basics of history teaching. Teachers often demonstrate their incapability as a history teacher by inventing innovation of teaching models or utilizing methods of creative teaching.

The incapability of a history teacher to develop innovation in the method of history teaching can be caused by a few factors; they are: 1 . The dense of subjects that enables for taking short cuts, meaning ignoring effective and psychomotor aspects; 2 . The teacher is not knowledgeable and skillful enough for teaching history that attracts the attention of the students; and 3 . The teacher has the tendency to utilize one method of teaching for any and all materials without considering the characteristics of every conveyed topics. Apart from that, there are four interrelated components and become the reason of obstacles in history teaching to take place, which are: 1 . the history teacher are generally come from a poor knowledge of history due to intellectual weariness to expose history sources, in the form of objects, documents or literature. A history teacher can stimulate and develop theimagination of the students so that the teaching of history triggers the enthusiasm to learn; 2 . History books and the media of history teaching are 
still limited; and 4. The method of history teaching is generally not challenging the intellectuality of the students.

Repairing the method of history teaching not only triggers the interest of learning, but also is one of the instruments that plays a role in processing the students to achieve the best learning outcomes. An early step to revitalize the teaching method is trying to understand how the history subject is taught. There are at least five elements of the study of history that must be put into practice: 1. Variety: any study that is tedious will no doubt make the students burned out, bored and finally not interested. This occurs during the study of history for it focuses on the practice of speech method, and therefore creates an impression that the study of history is identical with the practice of speech method. Even a large fraction of history teacher assumes that history materials can be transferred in whole from the teacher's head to the students with the same method of study; 2. Presentation from facts to analysis: the study of history in various schools focuses on the facts of history and memorization of facts such as the subject, year of events and place of events. Ideally, the study of history is not only a transfer of knowledge, but also a transfer of value. It does not only teach students to become more intelligent, but also have a noble character, Thus, the study of history aims at developing knowledge and at the same time didactical, that the purpose of studying history is in order for the next young generations to gain the moral and knowledge from the experience of their ancestors.

According to Mestika Zed, it is not sufficient for student to be crammed with knowledge memorizing cognitive activities through the facts that are no longer living in the past, for as long as it has occurred (Kompas, 13 August 2005). Soedjatmoko (1976:15) stresses that teaching history must no longer use methods of history teaching that only focuses on presenting history facts. Teaching history must be directed at the analysis comprehension on the facts of history. This view is very important in practicing the teaching of history in order to prevent the concerns of Winamo Surachmad (1978 9), which students do not succeed at the ability to see and think historically, yet their knowledge of history are ceased and tied by a collection of data, facts, and names of people. Therefore, the study of history should not stop at the level of facts, but must also arrive at domain of analysis, 3. Open and dialogic: a practice of the study of history that is closed and tedious with the potential of involving students in a stiff class, which stimulates uninterested attitude. Therefore, a history teacher must design an open and dialogic study. Openness and dialogic study prevents teachers to see themselves as the sole source of truth in class because the paradigm of centered teacher is prone to having a class that is closed and incapable of developing student's creativity, which must no longer be practiced, and therefore shift to the paradigm of student centered; 4. Divergent: in line with the study of history that focuses on analysis and dialogic. The practice of principles of divergent is very important to prevent the study of history from solely conveying the facts of history, meaning the study of history yearns for problem solving by providing students the opportunity to analyze and create many ideas; 5 . Progressive: the study of history must be base on the principals of progressive. The new paradigm of today on history education 
must be progressive and a firm outlook of the future. In the event that history seeks to function as education, and therefore it must provide an intelligent solution relevant to the social situation of today. The emphasis of this principal is the extinction of the history subject with a three-dimensional character. The development of innovation in this study targets at improving the quality of the study of history through the maximization of historiography practice.

According to Paul L. Dressel and Dora Marcus (1982), teaching is not only knowing and passing on knowledge, but also an effort to inspire and assist students to learn. Teachers no longer become the centre of activities that specifies the movement of each and every student. In actual fact, it is the students who are the centre as they are free to think and act (Hicks et.al, 1970). This does not mean that the teacher has lost the responsibility, as teacher has a role as the manager of teaching (Nasution, 1995). Meanwhile, in the opinion of Eisner in (Craig, Mehrens, dan Clarizio, 1975) that teaching must be based on the creation of environment that enables students to learn.

The quality of teaching can be examined from some aspects, which are: the process, the characteristic of teacher, the learning outcomes (Lucio dan McNeil, 1969). All of the aspects are interrelated for the purpose of achieving the learning objectives. Meanwhile the purpose of learning (education) consists of three aspects, which are: cognitive, affective, and psychomotoric (Eggen, Kauchak, dan Harder, 1979). The purpose of cognitive is related with the development of student's intelligence, effectively associated with the development of social and emotional. Meanwhile psychomotor is correlated with the development of the student's skills. Thus, it can be said that quality teaching applies when it can develop the above aspects within the student's self. This view is in accordance with the opinion of Dick dan Reiser (1989) that quality teaching is the teaching that enables students to obtain the designated skills, knowledge and attitude.

Kauchak dan Eggen (1993) conditions a characteristic that a quality teacher must possess, which is: having high expectations to the students, providing examples of the acceptable behavior, teaching with high spirit, and willing to listen to the students; speaking proper language, deliveringlogical and continuous materials, conveying clear signs, accurate attention and conformity between verbal and actions are important in communicating effectively; teachers being on time, preparing the materials in advance, and good practice.

In general, teachers do not realize their role in developing the history subject. This is reflected from the frequency of teaching in schools receiving attention from the society. Evidently, the teaching of history is held in improper ways (Widja, 1989).

In the study of history (Bank, 1985), (Sylvester, 1973), and (Mays, 1974) were very much expecting the utilization of history sources, including ancient manuscript in the studies at schools. Students must make an effort to find evidences from events of the past (history sources), to process or criticize the sources, translate and prepare it to become a history criteria. Teachers no longer become the sole information source in class, but also play the role of various dimensions, as a mentor in student activities. The role of a student is similar to 
a professional historian. Even if only at the introductory level, they can collect, process, translate, and conclude the sources with a variety of methods. Ancient manuscript as source can be utilized as a device or data in analyzing history facts dependent on how the teachers and students handletheancient manuscript as the analysis source in the study of history. This method or technique is consequently referred to a historiography or the writing of history, and therefore the utilization of ancient manuscript, for the analysis study on history events conducted by students together with the teachers will present "wholeness" on the study of history as a story and fact. This method is expected to stimulate students in analyzing historical events.

\section{Conclusion}

History is invaluable to a country. A great nation is a nation capable of appreciating its history as history can provide knowledge. History is a witness or evidence of a journey of a nation that not only presents memories, but also principals of life for today and for the future. In principal, the history of a nation is certainly the outcome of eliciting noble values by the respective nation. Therefore, the wisdom of a nation and, at the same time, the character of a nation can be obtained from many history writings.

According to W.J.S. Poerwadarminta (1984: 445), character is a behavior, disposition, psychological nature, moral, or character that differentiates one person to another. Thus in short, the character of a nation is thenature or character owned by a nation. History, according to W.J.S. Poerwadarminta (1984: 445) signifies as stories or past events of humans. From this notion, it is clearly stated that history is related with any and all that occurred in the past. Meanwhile the media, according to menurut Romiszowski dalam Basuki Wibawa (2001: 12), is signified as the messenger that derives from a message source (that can be in a form of a person or object) to the receiver of the message. Based on that opinion, the media of study can be suggested as a tool that is utilized to convey a message in a study. There are many media of study, for example, film, cassette, DVD, and even ancient manuscripts are considered as a media of study.

Theignorance of the community on the history of thenation must be overcome immediately due to its importance to the prolonging of the nation itself. As stated by Wang Gungwu dalam T. Ibrahim Alfian (1985: 3) that history has several purposes, which are: 1 . to preserve a collective identity and strengthening the durability of the community for the prolonging of life; 2 . to obtain knowledge and model from examples in the old days that provides principles of benefit in particular for its continued survival; 3 . to serves as a medium of comprehending the purpose of living and dying.

The explanation of Wang Gungwu above provides us with a comprehension that history shall never be forgotten. History that has been travelled through is not only related to stories, but a history of a nation is accompanied with important documents, including ancient manuscripts. The ancient manuscript in General 
Dictionary of Indonesian Language by W.J.S. Poerwadarminta is signified as a collection of important letters. The storing of ancient manuscripts is not without any reason, yet the goal to be achieved is particularly for the building of the character of a nation. As we currently know, it has been the public's secret that the character of Indonesia is very poor. The damaging of character is proven by the spreading of corruption, officials that are easily bought, the diminution of the sense of unity, and the increasing number of recent conflicts within Indonesia. Character building is valued as the primary key to advance the coexistence of Indonesia with a better condition of character.

Character building can be performed by studying ancient manuscripts that are part of the history of Indonesia. The correlation between life as a nation and a state and the existence of an ancient history becomes more important, because ancient manuscript is relevant to the journey of a nation. Furthermore, ancient manuscript is an accurate information source and serves as authentic evidence. The importance of ancient manuscript concerns the potential content of the kept information, which are 1. Recognition of collective memory through ancient manuscript; 2 . Ancient manuscript serves as a media to uncover behind the facts; and 3. Ancient manuscript as an investigation of study. From the explanation above, we can clearly understand and acknowledge how important an ancient manuscript is for our lives, as part of the history of the nation and serves as authentic evidence. The ancient manuscript is not only worn-out papers. Nonetheless, behind those papers lies a very important and precious knowledge, particularly those that can build the character of the nation.

As we know, a great nation is a country that is capable of appreciating its history. This appreciation can be realized by studying a fraction of history, which is the ancient manuscript. In the character building, ancient manuscript plays a major role; for example, by studying the ancient manuscript, the society will learn the lineage of its own nation from the stories, tales, and facts conveyed through the ancient manuscript. This is required to help build the character of our nation today.

Considering the importance of the history for our lives, and therefore as Indonesian nation, we must learn and understand it. History serves as a teacher that provides invaluable lessons for the survival of this nation. Studying history can commence from studying the ancient manuscript for it is the main part of the journey of the Indonesian history. Studying ancient manuscripts is an attempt to build the character of Indonesia that needs to be recovered.

Through ancient manuscripts, the community of Indonesia is capable of learning the value of lives that are contained in the ancient manuscripts. The ancientmanuscriptcommonlyutilizesscriptedlanguageorliteracy thatsymbolizes amiable, humanity values, symbol of self expression, spiritual, attitude, ethnical, culture, art, as well as marking the era of writing by the author, including a wideranging life such as philosophy, religion, beliefs, business, domicile, as well as expertise and other skills.

Many manuscripts are copied because of their vulnerable age. Copying is also one of the methods to preserve an ancient manuscript. Today, ancient 
manuscripts can be found in the national library or regional library. There are many collectors who keep them for the sole purpose of collecting. The existing manuscripts spread all over the world enrich our own manuscripts; nonetheless, only a few are still in a mint condition and many are copies. Recopying is one of the many ways of preserving the existence of rare manuscripts. There are many manuscripts that are unknown of their whereabouts, which causes them to be neglected and even damaged.

For today's society, manuscripts generally function as a scarce item that is stored as an antique object. Some of our community has not realized the significance contained in a manuscript According to the writer, the existing ancient manuscript is beneficial for the study of history, particularly as a source of analysis from a history source that can be mutually learned by the teacher and student in class. Ancient manuscript can serve as a study and reference for the development of history. 


\section{REFERENCES}

Dudung, A. (2007). Metodologi Penelitian Sejarah. J ogjakarta: Ar-Ruzz Media. Kuntowijoyo. (1994). Metodologi Sejarah. Yogyakarta: Pt. Tiara Wacana.

Alfian, dkk. (1984). Bunga Rampai Metode Penelitian Sejarah. Yogyakarta: LERES IAIN Sunan Kalijaga.

W.J .S. Poerwadarminta. (1984). Kamus Umum Bahasa Indonesia.J akarta: Balai Pustaka.

Bank, J. A. (1985). Teaching Strategies for the Social Studies, New York: Longman, Inc.

Craig, R.C., Mehrens, William A., dan Clarizio, Harvey F. (1975). Contemporary Educational Psychology. New York: J ohn Wiley and Sons, Inc.

Dick, W, dan Reiser, R.A. (1989). Planning Effective Instruction. Boston: Allyn and Bacon.

Gottschalk, L. (1981). Understanding History: A Primary of Historical Method (terj.) Nugroho Notosusanto, J akarta: Uneversitas Indonesia Press.

Hamid, S.H. (1985). Pengajaran sejarah antara Harapan dan Kenyataan. Makalah. Seminar Sejarah Nasional di Yogyakarta.

Hopkins, D. (1993). A Teacher's Guide to Classroom Research. Bristol: Open University Press.

Kasihani, K.( 2001). Penelitian Tindakan Kelas, Malang: Universitas Negeri Malang.

Kauchak, D.P. dan Eggen, P.D. (1993). Learning and Teaching, Research-Based Methods. Boston: Allyn and Bacon.

Nasution, S. (1995). Didaktik Asas-asas Mengajar. J akarta: Bumi Aksara.

Sylvester, D. (1973). Teaching History. London: Grom Helm, Ltd.

Tilaar, H.A.R. (1993). "Dirregulasi Pendidikan Nasional dalam Rangka Implementasi UU No 2 Tahun 1989 pada Repelita VI'. Buletin LPMP, No. 4. J akarta: LPMP - IKIP J akarta.

Widya, I Gde. (1989). Pengantar Ilmu Sejarah dalam Perspektif Pendidikan. Semarang: Satya Wacana. 
UFI SARASWATI

The Signification and Purpose of Ancient Manuscript for The Nation's Culture and Character Development Through The Story Teaching 